\title{
Characteristics and Antioxidant Activity of Kebar Grass (Biophytum petersianum) Extract
}

\author{
Aminudin $^{1 *}$, Nuri Andarwulan ${ }^{1,2}$, Nurheni Sri Palupi $^{1,2}$, Iis Arifiantini ${ }^{3}$ \\ ${ }^{1}$ Department of Food and Science Technology, IPB University, Indonesia \\ ${ }^{2}$ Southeast Asian Food \& Agricultural Science \& Technology (Seafast) Center, IPB University, Indonesia \\ ${ }^{3}$ Department of Veterinary Clinic Reproduction and Pathology, IPB University, Indonesia \\ *Email: andarwulan@apps.ipb.ac.id
}

Submitted: 21 March 2020. Revised: 26 May 2020. Accepted: 1 June 2020

\begin{abstract}
Kebar grass (Biophytum petersianum Klotzsch.) has long been known by the locals of West Papua as medicinal plant that improves fertility. The objectives of this research were to identify and determine the antioxidant activity of kebar grass crude extract through conventional method and to analyze for its antioxidant activity. Extraction method used was conventional method, performed by mixing dry kebar grass with water and boiled until the volume shrunk to $1 / 3$ of initial volume. Analized parameters were crude extract yield, qualitative phytochemical, total phenol and antioxidant activity. Research result showed extract crude yield value of $18.32 \pm 0.01 \%$. Qualitative phytochemical contents were dominated by flavonoid, tannin, and saponin. Total phenolic content (TPC) of crude extract was $147 \pm 1.24 \mathrm{mgGAE} / \mathrm{gdw}(0.688 \pm 0.01 \mathrm{mgGAE} / \mathrm{gfw})$. Crude extract antioxidant parameter was measured as the value of inhibition, AEAC, TEAC, and $\mathrm{IC}_{50}$ where each value respectively was as followed $42.0 \pm 0.047 \%, 69.93 \pm 2.19 \mathrm{mgAE} / \mathrm{gdw}(8.30 \pm 0.26$ $\mathrm{mgAE} / \mathrm{gfw}), 65.70 \pm 1.54 \mathrm{mgTE} / \mathrm{gdw}(7.80 \pm 0.18 \mathrm{mgTE} / \mathrm{gfw})$ and $0.129 \pm 0.003 \mathrm{mgdw}(257.75 \pm 4.90 \mathrm{mg} / \mathrm{L})$. The contribution of kebar grass TPC content to antioxidant activity is $47.38 \%$ (equal to ascorbic acid) and $44.51 \%$ (equal to trolox) which means that almost half of kebar grass crude extract's phenolic compound act as antioxidant. The results of this research can show that the kebar grass has potential as a source of multiple antioxidants, which acts as an analogue of vitamin C and vitamin E. The antioxidant activity of the kebar grass extract can be the scientific basis for the use of kebar grass as a medicinal plant for infertility problems (curative) and as a functional food ingredient for antioxidant sources that prevent a decrease in reproductive performance (preventive).
\end{abstract}

Key words: Kebar Grass; Conventional Extraction; Crude Extract; Yield; Antioxidant

How to Cite: Aminudin, A., Andarwulan, N., Palupi, N. S., \& Arifiantini, I. (2020). Characteristics and Antioxidant Activity of Kebar Grass (Biophytum petersianum) Extract. Biosaintifika: Journal of Biology \& Biology Education, 12 (2), 178-185

DOI: http://dx.doi.org/10.15294/biosaintifika.v12i2.23820

\section{INTRODUCTION}

Prevention and treatment of various diseases can be performed by drugs from chemical medicine or from plants. Recently, prevention and treatment of various diseases tend to lean on natural means, which is to use plant as medicinal source. The use of plants as medicine is researched more vigorously and become a priority in medical world since it is deemed to be safer and cheaper. One of the diseases that has been treated by medicinal plants is infertility (Mbemya et al., 2017). Many plants that has long been used as an alternative medicine in treating infertility problem are Eurycoma longifolia Jack. (Pratomo, 2012), Cordyline fruticosa (Amudha \& Rani, 2016), and Chlorella vulgaris (Hernayanti \& Simanjuntak, 2019). Plant ability to resolve infertility is assumed to be caused by the bioactive compound compositions which can influence folliculogenesis and steroidogenesis. These bioactive compounds have antioxidant characteristics and an ability to regulate several enzymes in steroidogenesis and as reactive oxygen species (ROS) scavenging agent in ovary cells or able to regulate the production of hormones in ovary (Telefo et al., 2012). Bioactive compound consumption as polyphenols in food or drink can increase antioxidant capacity in the body (Ly et al., 2015) and lower oxidative stress in reproductive organ (Chen \& Chan, 2012). Antioxidant supply from diet can complement endogenous antioxidant and together contain the action against free radicals (Ly et al., 2015). Bioactive compounds with effects on influencing reproduction are alkaloid, phenol, flavonoid, and phytosterol whose maximum contents are contained in plants (Adhikari et al., 2018). Vitamin E within a certain level is known to normalize epithelial cell of tubulus seminiferus and repair epithelial cell, contributing to an increase in testicle mass (Handayaningsih, 2010).

Kebar grass (B. petersianum) is among endemic plants originating from West Papua province, more specifically Kebar District, Tambrauw Regency. Kebar grass $(\mathrm{KG})$ plant is categorized in Plantae kingdom, Spermatophyte division, Angiospermae subdivision, Dicotyledoneae class, Geraniales ordo, Oxalidacea family, Biophytum genus, and petersianum species (Hyde et al., 2020). KG has long been known by the locals of West Papua as medicinal plant that improves fertility. Other than for treatment, $\mathrm{KG}$ is also reported to inhibit aflatoxin produced by A. flavus fungi in food high in carbohydrate, protein, and 
lipid (Lisangan et al., 2014). Outside of Indonesia, a type of $\mathrm{KG}$ is found in Mali and other African regions. The plant in that region is named B. umbraculum Welw. and by locals, used as malaria medicine and cure for wound, stomach pain, and kidney stone (Hyde et al., 2020). Today, KG is commercialized as primary commodity in the form of whole dry grass. Difficulties in KG marketing among them are the lack of knowledge on its benefits for people outside of Papua, the product that is sold in the form of whole plant, and comprehensive efficacy study that is yet to be performed. This research aimed to identify and determine the characteristics of KG extract after conventional extraction and to analyze its antioxidant activity. Further benefits of the results of this study are as a scientific basis for the development of $\mathrm{KG}$ products that are applicable as an alternative medicinal plant for infertility healing (curative) and as a functional food ingredient for sources of antioxidants that prevent a decrease in reproductive performance (preventive).

\section{METHODS}

The main material used was fresh KG. Chemical ingredients used were methanol, $n$-hexane, chloroform, ethyl acetate and Folin-Ciocalteau's phenol reagent from E-Merck (Darmstadt, Germany). There were also Trolox (6-hydroxy-2,5,7,8tetramethylchroman-2-carboxylic acid), ascorbic acid and DPPH (2,2-diphenyl-1-picrylhydrazyl) from Sigma-Aldrich (St. Louis, MO, USA) and distilled water.

\section{Sample identification and preparation}

KG sample identification was performed in Botany Laboratory of Indonesian Institute of Science, Bogor. KG sample preparation for the tests was conducted by preparing fresh KG for fresh weight content and for the examinations on water content of dried $\mathrm{KG}$, crude extract characteristics, qualitative phytochemical, and antioxidant activity. Fresh KG was sorted and cleaned from dirt and then dried under the sun until the water content reached below $10 \%$ and then grounded to obtain coarse powder and mashed in sieve 30 mesh (Andarwulan et al., 2012). The fine KG powder of 30 mesh size was packaged in $25 \mathrm{~g}$ each and then put into dark plastic container before being stored in freezer $\left(-20^{\circ} \mathrm{C}\right)$ until the analysis time.

\section{Water content analysis}

Water content analysis was performed according to gravimetry method (Andarwulan et al., 2010). This test began by drying the aluminium cup in an oven on $105^{\circ} \mathrm{C}$ for 3 hours. The cup was then placed in a dessicator until cool $( \pm 30$ minutes). The cup was weighted to obtain dry cup weight $\left(\mathrm{W}_{0}\right)$. Sample was put into dry cup and weighted along with the cup $\left(\mathrm{W}_{1}\right)$. The cup was then put into an oven for 3 hours in $105^{\circ} \mathrm{C}$ and then cooled in dessicator. The procedure was repeated until a stable weight was obtained $\left(\mathrm{W}_{2}\right)$. Water content was measured using the following equation:

Water Content $(\%$, ary basis, $d b)=\frac{W_{1}-W_{2}}{W_{1}-W_{0}}$

\section{Sample extraction}

KG extraction adopted a conventional method. Dry KG of $30 \mathrm{~g}$ was mixed with $600 \mathrm{~mL}$ water (1:20). In this research, modification was applied since fine $\mathrm{KG}$ powder was used. The mixture of fine KG powder and water was boiled until the mixture volume was $1 / 3$ part of initial volume, then the mixture was strained and cooled. The mixture was sonicated with ultrasonic bath (Bransonic Ultrasonic Cleaner $8510 E$ MTH, Branson ultrasonic Corp USA) for 30 minutes in room temperature, centrifuged in $2000 \mathrm{rpm}$ for 5 minutes, and filtrated with filter paper Whatman no.42. The residual pulp was re-extracted with water in ratio of 1:2 (Sasidharan et al., 2011; Juliani et al., 2016). All of filtrate was contained in dark bottle. The solvent of the filtrate was evaporated via the use of rotary evaporator (Buchi Rotavapor R-210, Buchii Labortechnik Switzerland) in $50^{\circ} \mathrm{C}$ with 264 mbar pressure (Rütti \& Heierli, 2012) until a thick extract was obtained. Thick extract was dried by blowing $\mathrm{N}_{2}$ gas to obtain dry extract. The end product of this extraction was called water-soluble kebar grass crude extract (CE). The yield of extraction process was measured with the following equation:

$$
\text { Extract yield }(\%)=\frac{\text { CE weight }}{\text { Fine KG weight }} \times 100 \%
$$

\section{Qualitative phytochemical analysis}

CE qualitative phytochemical analysis was conducted to identify qualitatively the presence of secondary metabolites contained in KG and was determined by the method of Iqbal et al. (2015) and Thouri et al. (2017). The result of qualitative analysis on the presence of phytochemicals was symbolized as $(+)$ if present and (-) if none. Alkaloid tests were carried out using Mayer, Wagner and Dragendorf (MWD) reagents and produced colored sediment with the changing color of MWD in the order of white, brown, and orange red. Test of flavonoid was carried out using sample mixture with flavonoid reagent (mixture of $\mathrm{MgO}, \mathrm{HCl}$ and amyl alcohol) and then produce red, yellow, and orange as signified the presence of flavonoid. For saponin test, it was done by boiling sample with water then chilling and the presence of saponin was shown by stable bubbles. For tannin test, the method was the same as saponin but the filtrate was poured into a tube and then dripped with $\mathrm{FeCl}_{3} 1 \%$. 
The presence of tannin was signified by greenish black color. Test of triterpenoid and steroid were done by added ethanol to the sampe and then boiled, filtered, and heated until dry. Dry filtrate was then added by $1 \mathrm{~mL}$ diethyl ether, homogenized and divided into two. For steroid test, the solution was added by 1 drop of concentrated $\mathrm{H}_{2} \mathrm{SO}_{4}$. Solution color change into green or blue signified the presence of steroid. For triterpenoid test, it was added by 1 drop of acetic anhydride. The changing color of the solution into red or violet showed the presence of triterpenoid. Quinone test was done by added methanol to the sample, heated, and filtered. The filtrate was then added by 3 drops of $\mathrm{NaOH} 10 \%$. The quinone was signified by red color.

\section{Total phenolic content (TPC) analysis of CE}

Total phenolic content (TPC) was analyzed using Folin-Ciocalteu reagent for colorimetric determination by the method of Adebayo et al. (2018) with several modifications. Sample was mixed with FolinCiocalteu reagent $10 \%$, and natrium carbonate $7.5 \%$ (1:5:4). The absorbance of the mixture was measured under $765 \mathrm{~nm}$ wavelength with UV-Vis Spectrophotometer. As a standard, gallic acid was used in $1-40$ $\mathrm{mg} / \mathrm{L}$ concentration. TPC was stated in $\mathrm{mgGAE} / \mathrm{gdw}$ (gfw), milligram gallic acid equivalent per gram dry weight (gram fresh weight).

\section{Antioxidant analysis with DPPH method}

Antioxidant analysis therein included inhibition power, ascorbic acid equivalent antioxidant capacity (AEAC), trolox equivalent antioxidant capacity (TEAC) and $\mathrm{IC}_{50}$. DPPH antioxidant analysis was measured according to the method by Iqbal et al. (2015) with several modifications. Extract/standard (in methanol) was mixed with DPPH reagent (comparison volum being $1: 1$ ). Absorbance measurement was conducted at $517 \mathrm{~nm}$ wavelength. Ascorbic acid and Trolox were used as standard with $0.391-25$ $\mathrm{mg} / \mathrm{L}$ concentration. Regression curve was obtained from inhibition value converted into absorbance value. $\mathrm{IC}_{50}$ value was calculated by the interpolation of regression equation curve. Antioxidant inhibition power was separated into 4 categories: $0 \%$ - 20\% (low), 20\% - 40\% (moderate), $40 \%-80 \%$ (good) and $80 \%-100 \%$ (very good) (Nahak et al., 2014). Antioxidant inhibition value could then be used to determine the antioxidant capacity of $\mathrm{CE}$, stated in ascorbic acid equivalent antioxidant capacity (AEAC, $\mathrm{mgAE} / \mathrm{gdw}$ ) and trolox equivalent antioxidant capacity (TEAC, $\mathrm{mgTE} / \mathrm{gdw}$ ). Inhibition value (percentage of free radical scavanger) of sample against DPPH radicals was obtained by measuring control absorbance (Ao) and sample/standard absorbance (As). Inhibition value was measured by the following equation:
$\%$ inhibition $=\frac{(\mathrm{AO}-\mathrm{As})}{\mathrm{AO}} \times 100 \%$

\section{The relationship between TPC with antioxidant activity}

The relationship between TPC (mgGAE/gfw) with antioxidant activity of the KG plant (mgAE/gfw and mgTE/gfw) can provide an overview of how much contribution a plant has from its antioxidant activity. Bioactive compound contribution in a plant is represented as TPC with the compound ability in inhibiting free radical calculated with the following equation:

\% Bioactive compound contribution on antiosidant capacity $=\frac{(\mathrm{AA})}{(\mathrm{TPC})} \times 100 \%$

In which, AA: antioxidant activity (AEAC value; TEAC value); and TPC: total phenolic content.

\section{Data analysis}

Data (average \pm deviation standard) obtained from every parameter was analysis by analysis of variance (Anova) and to see the difference between treatments, the analysis was followed by Duncan test with $\alpha=0.05$ by using software SPSS Version 21 .

\section{RESULT AND DISCUSSION}

\section{Identification of kebar grass plant}

Based on the result of identification, the sampel tested was KG with scientific name Biophytum petersianum Klotzsch (Figure 1). KG physical characteristics based on its natural habitat in Kebar Regency have maximum leaf number of 8 pairs with oval leaf and a single flower attached to the tip of short stem of around $1 \mathrm{~mm}$ in length. KG morphological characteristics consist of very short peduncle, few flowering clustered in the middle of rosette leaf, pedicel 2-3 $\mathrm{mm}$, calyx 4-5 mm, part of petal colored yellow, orange, or red, small seed, round-oval leaf shape, 3-9 pairs of leaflets, pinnate leaf veins perpendicular against leaf bone with generally one season life span (Hyde et al., 2020). This species was identical with kebar grass plant sample used for this research for having the same characteristics.

\section{Water content and extract yield}

Water content measurement of KG sample was performed on 3 types of sample conditions: fresh, dry, and crude extract sample. Based on the result (Table 1), water content of fresh $\mathrm{KG}$ was $59.17 \pm 0.00 \% \%$ (db, dry basis), dry KG was $8.97 \pm 0.016 \%$ (db) and crude dry extract (crude extract) was $0.29 \pm 0.0012 \%$ $(\mathrm{db})$. 

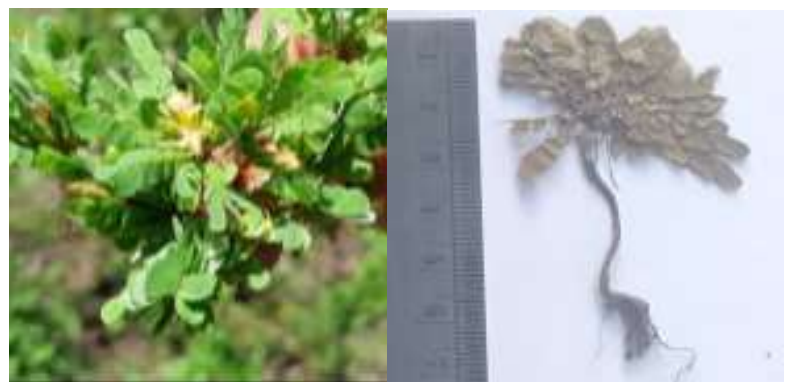

Figure 1. KG plant (left picture: fresh KG in the habitat; right picture: dried $\mathrm{KG}$ )

Extract yield in the form of $\mathrm{CE}$ in this research was $18.32 \pm 0.01 \%$. Plant in the same genus but different species Biophytum sensitivum (L.) extracted by methanol solvent produced a yield of $11.6 \%$ (Kumar et al., 2017). This different yield showed that species difference and solvent type will produce different amount of yield. The difference of yield value is also influenced by the method of extraction. This can be seen on Table 2 which presents the different KG yield value produced by different extraction methods and types of solvent used.

Table 1. Water content of kebar grass samples in percent dry basis

\begin{tabular}{cc}
\hline $\begin{array}{c}\text { Type of } \\
\text { sample }\end{array}$ & $\begin{array}{c}\text { Water con- } \\
\text { tent }\end{array}$ \\
\hline Fresh & $59.17 \pm 0.00$ \\
Dry & $8.97 \pm 0.016$ \\
Extract & $0.29 \pm 0.0012$ \\
\hline
\end{tabular}

Table 2. Extract yield of KG with various extraction methods and types of solvent

\begin{tabular}{llll}
\hline Extraction methods & Solvent & Yields $\left.(\%)^{*}\right)$ & References \\
\hline Conventional & Water & $18.32 \pm 0.01^{\mathrm{a}}$ & This research \\
72 hours maceration & Ethanol $70 \%$ & $19.82^{\mathrm{a}}$ & Claudya et al. (2016) \\
72 hours maceration & Ethanol $50 \%$ & $12.00^{\mathrm{b}}$ & Titrikou et al. (2007) \\
1 hour maceration & Methanol & $14.17^{\mathrm{b}}$ & Lisangan et al. (2014) \\
1 hour maceration & Water temperature of $60^{\circ} \mathrm{C}$ & $3.28^{\mathrm{c}}$ & Lisangan et al. (2014) \\
1 hour maceration & Ethyl acetate & $6.15^{\mathrm{d}}$ & Lisangan et al. (2014) \\
1 hour maceration & n-hexana & $2.94^{\mathrm{c}}$ & Lisangan et al. (2014) \\
\hline
\end{tabular}

*) different notation in yields column shows significant difference $(\mathrm{p}<0.05)$

Table 2 shows that the yield of KG extract in the conventional method is very high $(\mathrm{p}<0.05)$ compared to other yields, except for the yield of extraction with $70 \%$ ethanol solvent. This result can give an illustration that bioactive components in $\mathrm{KG}$ are easily extracted by using polar solvent (yield $>10 \%$ ) but are hard to extract by semi polar to non polar solvent (yield $<10 \%$ ). However, in other plants the opposite occurs, namely extraction with organic solvents produces a higher yield compared to water solvents. As an example yield of $S$. chinensis $\mathrm{L}$. root is influenced by the type of solvent used during extraction process, where absolute methanol solvent produced the highest yield followed by 50\% ethanol, 50\% methanol, 50\% acetone, and water (Ngo et al., 2017). Other reports which support this statement were researches of several fresh vegetables (Sulaiman et al., 2011) and date seed (P. dactylifera L.) (Thouri et al., 2017).

\section{Qualitative phytochemical analysis}

Based on this research, the result of qualitative phytochemical analysis showed that flavonoid, tannin, and saponin are present (Table 3). Other report showed that $\mathrm{KG}$ extract contained steroid, quinone and triterpenoids other than flavonoid, tannin, and saponin (Lisangan et al., 2014). Detection of other components other than the result of this research is assumed to be caused by its extraction process and the use of 3 types of solvent in steps which were hexant, ethyl acetate, and methanol (Lisangan et al., 2014). This allows non polar components such as steroid to be extracted, whereas this research used conventional extraction with a single solvent, water. Based on Table 3, alkaloid, quinone, steroid, and triterpenoid component appeared to be undetected by using the extraction method used in this research. This is because alkaloid is a component easily soluble in semipolar solvent, while steroid, quinone, and triterpenoid tend to dissolve in non-polar solvent, so these compounds will not be detected in water (polar) solvents (Harborne,1998). Polar compounds such as phenol and flavonoid will be easily extracted by solvent with high polarity besides being influenced by the type of plant (Thouri et al., 2017). The statement reinforces the results of this study where conventional KG extraction produces high concentrated flavonoid, tannin, and saponin components. This can explain that if the target compound in $\mathrm{KG}$ extraction is a polar component, the solvent used is the polar solvent and then, It is assumed that other compound components that are semi-polar and non polar are still chained within EC matrix. In order to maximize the extraction of other bioactive components, fractionation could be chosen. 
Table 3. Qualitative phytochemical analysis of KG

\begin{tabular}{ll}
\hline Test & Results \\
\hline Flavonoids & ++ \\
Tannin & +++ \\
Alkaloid & - \\
Saponin & ++ \\
Quinon & - \\
Steroid & - \\
Triterpenoid & - \\
\hline
\end{tabular}

Note: $(+)=$ detected; $(-)=$ not detected .

\section{Total phenolic content (TPC) analysis from crude extract (CE)}

Results of TPC analysis of CE and the comparison of those data with other samples is presented on Table 4. From test result, TPC value of CE was $147 \pm 1.24$ $\mathrm{mgGAE} / \mathrm{gdw}(0.688 \pm 0.01 \mathrm{mgGAE} / \mathrm{gfw})$. Report of other research mentioned the TPC value of $B$. petersianum Klotzsch being $205 \mathrm{mgGAE} / \mathrm{gdw}$ (Titrikou et al., 2007) while TPC value of $B$. sensitivum to be 87.0 $\pm 0.404 \mathrm{mgGAE} / \mathrm{gdw}$ (Kumar et al., 2017). From the three TPC data, differences can be observed. The differences of this TPC value are thought to be due to the different type of sample, extraction method, and solvent used. This research used conventional method with water, while other research used maceration method with respective solvents being ethanol (Titrikou et al., 2007) and methanol (Sulaiman et al., 2011). This statement is also supported by other researches mentioning TPC with varied value as seen on Table 4.

Comparing the research result data of several Indonesian local plant with medicinal properties such as katuk (S. androgynus (L) Merr), kenikir (C. caudatus H.B.K), kecombrang (E. elatior (Jack) R.M.Sm), and antanan (C. asiatica), their TPC value ranged between 0.21 up to $8.47 \mathrm{mgGAE} / \mathrm{gfw}$ (Andarwulan et al., 2012) while KG plant TPC value was $0.69 \pm 0.01$ mgGAE/gfw. This means the TPC value of KG plant is included as relatively high TPC. The potential of $\mathrm{KG}$ as a source of medicinal plants is very relevant because it is strengthened by a relatively high TPC value of $147 \pm 1.24 \mathrm{mgGAE} / \mathrm{gdw}$. In comparison, TPC values of several medicinal plants that are spread all over in India such as T. cordifolia, C. rotundus, P. marsupium, $\mathrm{T}$. arjuna, A. nilotica only range between 0.52 to $15.88 \mathrm{mgGAE} / \mathrm{gdw}$ (Rajurkar \& Hande, 2011). Another comparison of KG TPC value is with several medicinal plants that are widely spread in the Asian continent such as G. umbrosus, A. dolichocarpa, M. peregrinum which ranges from 1 to 400 mgGAE / gdw (Iqbal et al., 2015), as well as with vegetable plants commonly consumed in Malaysia ranging from 0.1 to $138.2 \mathrm{mgGAE} / \mathrm{gdw}$ (Sulaiman et al., 2011). Thus, KG plant has very strong potential as plants with medicinal properties.

\section{Antioxidant activity analysis with DPPH method}

Results of CE antioxidant activity analysis, inhibition power, AEAC, TEAC, and $\mathrm{IC}_{50}$ respectively are $42.0 \pm 0.047 \% \quad$ (good), $\quad 69.93 \pm 2.19 \quad \mathrm{mgAE} / \mathrm{gdw}$ $(8.30 \pm 0.26 \mathrm{mgAE} / \mathrm{gfw}), \quad 65.70 \pm 1.54 \mathrm{mgTE} / \mathrm{gdw}$ $(7.80 \pm 0.18 \mathrm{mgTE} / \mathrm{gfw})$ and $0.129 \pm 0.003 \mathrm{mgdw}$ $(0.258 \pm 0.0049 \mathrm{mg} / \mathrm{mL})$. The $\mathrm{IC}_{50}$ value of ascorbic acid (AA) was $1 / 10$ and $\mathrm{IC}_{50}$ of trolox (T) was $1 / 12$. Thus, crude extract of kebar grass has the potency as antioxidant component associated with ascorbic acid which is included as polar compound group and with Trolox that tend to be non polar compound.

Table 4. Comparison of TPC kebar grass crude extract with other plants

\begin{tabular}{|c|c|c|c|c|}
\hline Samples & $\begin{array}{l}\text { Extraction } \\
\text { methods }\end{array}$ & Solvent & TPC & References \\
\hline B. petersianum & Conventional & Water & $\begin{array}{l}147 \pm 1,24 \mathrm{mgGAE} / \mathrm{gdw} \\
(0.69 \pm 0.01 \mathrm{mgGAE} / \mathrm{gfw})\end{array}$ & This research \\
\hline B. petersianum & $\begin{array}{l}72 \text { hours macer- } \\
\text { ation }\end{array}$ & Ethanol $50 \%$ & $205 \mathrm{mgGAE} / \mathrm{gdw}$ & $\begin{array}{l}\text { Titrikou et al. } \\
\text { (2007) }\end{array}$ \\
\hline B. sensitivum & $\begin{array}{l}24 \text { hours macer- } \\
\text { ation }\end{array}$ & Methanol 50\% & $87.0 \pm 0.404 \mathrm{mgGAE} / \mathrm{gdw}$ & $\begin{array}{l}\text { Kumar et al. } \\
\text { (2017) }\end{array}$ \\
\hline $\begin{array}{l}\text { Vegetables of Indonesian } \\
\text { origin }\end{array}$ & Shaking & Etanol 95\% & $0.21-8.47 \mathrm{mgGAE} / \mathrm{gfw}$ & $\begin{array}{l}\text { Andarwulan et al. } \\
\text { (2012) }\end{array}$ \\
\hline Medicinal plants in India & $\begin{array}{l}5 \text { hours macera- } \\
\text { tion }\end{array}$ & $\begin{array}{l}\text { Methanol ab- } \\
\text { solut }\end{array}$ & 0.52-15.88 mgGAE/gdw & $\begin{array}{l}\text { Rajurkar \& } \\
\text { Hande (2011) }\end{array}$ \\
\hline $\begin{array}{l}\text { Common medicinal } \\
\text { plants in Asia }\end{array}$ & $\begin{array}{l}10 \text { hours } \\
\text { soxhletation }\end{array}$ & $\begin{array}{l}\text { Methanol ab- } \\
\text { solut }\end{array}$ & $1.00-400.00 \mathrm{mgGAE} / \mathrm{gdw}$ & $\begin{array}{l}\text { Iqbal et al. } \\
(2015)\end{array}$ \\
\hline \multirow[t]{4}{*}{$\begin{array}{l}\text { Vegetables commonly } \\
\text { consumed in Malaysia }\end{array}$} & $\begin{array}{l}1 \text { hour macera- } \\
\text { tion }\end{array}$ & $\begin{array}{l}\text { water destila- } \\
\text { tion }\end{array}$ & $\begin{array}{l}0.1-98.6 \mathrm{mgGAE} / \mathrm{gdw} \\
0.1-80.5 \mathrm{mgGAE} / \mathrm{gdw}\end{array}$ & $\begin{array}{l}\text { Sulaiman et al. } \\
\text { (2011) }\end{array}$ \\
\hline & & Metanol 70\% & $0.3-120.5 \mathrm{mgGAE} / \mathrm{gdw}$ & \\
\hline & & Etanol 70\% & 0.4-138.2 $\mathrm{mgGAE} / \mathrm{gdw}$ & \\
\hline & & Aseton $70 \%$ & & \\
\hline
\end{tabular}


Table 5. Comparison of kebar grass antioxidant activity with other plants

\begin{tabular}{|c|c|c|c|c|c|}
\hline \multirow{2}{*}{$\begin{array}{l}\text { Sampel } \\
\text { Crude extract } \\
\text { of kebar grass }\end{array}$} & Inhibition (\%) & AEAC & TEAC & $\mathrm{IC}_{50}$ & References \\
\hline & $42.0 \pm 0.047 \%$ & $\begin{array}{l}69.93 \pm 2.19 \\
\mathrm{mgAE} / \mathrm{gdw} \\
(8.30 \pm 0.26 \\
\mathrm{mgAE} / \mathrm{gfw})\end{array}$ & $\begin{array}{l}65.70 \pm 1.54 \\
\mathrm{mgTE} / \mathrm{gdw} \\
(7.80 \pm 0.18 \\
\mathrm{mgTE} / \mathrm{gfw})\end{array}$ & $\begin{array}{l}0.129 \pm 0.003 \mathrm{mgdw} \\
(0.258 \pm 0.0049 \\
\mathrm{mg} / \mathrm{mL}) \\
0.012 \pm 0.001 \mathrm{mgdw} \\
(\mathrm{AA}) ; 0.01 \pm 0.0003 \\
\text { mgdw (Tr) }\end{array}$ & This research \\
\hline $\begin{array}{l}\text { Crude extract } \\
\text { of } B \text {. sensi- } \\
\text { tivum }\end{array}$ & nd & nd & $\mathrm{Nd}$ & $\begin{array}{l}0.164 \pm 0.0004 \\
\mathrm{mg} / \mathrm{mL}\end{array}$ & $\begin{array}{l}\text { Kumar et al. } \\
(2017)\end{array}$ \\
\hline $\begin{array}{l}\text { Vegetables of } \\
\text { Indonesian } \\
\text { origin }\end{array}$ & nd & $\begin{array}{l}0.12-4.94 \\
\mathrm{mgAE} / \mathrm{gfw}\end{array}$ & $\begin{array}{l}0.67-10.90 \\
\mathrm{mgTE} / \mathrm{gfw}\end{array}$ & nd & $\begin{array}{l}\text { Andarwulan et } \\
\text { al. (2012); } \\
\text { Andarwulan et } \\
\text { al. (2010) }\end{array}$ \\
\hline $\begin{array}{l}\text { Medicinal } \\
\text { plants in In- } \\
\text { dia }\end{array}$ & $\begin{array}{l}7.83 \pm 0.26- \\
29.12 \pm 0.30\end{array}$ & $\begin{array}{l}46.9-224 \\
\mathrm{mgAE} / \mathrm{gdw}\end{array}$ & $\begin{array}{l}0.22-13.69 \\
\mathrm{mgTE} / \mathrm{gdw}\end{array}$ & $\begin{array}{l}0.061-1.946 \\
\mathrm{mg} / \mathrm{mL}\end{array}$ & $\begin{array}{l}\text { Datta et al. } \\
\text { (2019); Sreeram- } \\
\text { ulu et al. (2013) }\end{array}$ \\
\hline $\begin{array}{l}\text { Vegetables of } \\
\text { Thailand } \\
\text { origin }\end{array}$ & nd & nd & nd & $\begin{array}{l}4.23 \pm 0.01- \\
11.05 \pm 0.13 \mathrm{mg} / \mathrm{mL}\end{array}$ & $\begin{array}{l}\text { Rattanasena } \\
(2012)\end{array}$ \\
\hline
\end{tabular}

Note: $\mathrm{nd}=$ no data.

Based on the comparison of $\mathrm{KG}$ antioxidant ability with other plants with medicinal properties (Table 5), it can be seen that inhibition power and antioxidant activity (AEAC and TEAC) of KG plant is relatively high compared to other plants. If compared with several Indonesian vegetables plant such as jambu monyet leaf $(A$. occidentale $)$, angsoka/beluntas $(P$. indica), kenikir (C. caudatus), and takokak (S. torvum) which have AEAC value ranging from 0.12 to $4.94 \mathrm{mgAE} / \mathrm{gfw}$ (Andarwulan et al., 2012), KG's AEAC value is considerably high $(8.30 \pm 0.26$ $\mathrm{mgAE} / \mathrm{gfw})$. However, from the $\mathrm{IC}_{50}$ value it can be seen that $\mathrm{KG}$ has relatively low $\mathrm{IC}_{50}$ (see Table 5), unless compared to $B$. sensitivum. The $\mathrm{IC}_{50}$ value of $B$. sensitivum is lower than $\mathrm{KG} \mathrm{IC}_{50}$. The different results obtained from this research is assumed to be caused by differences in species, solvent and extraction method. In the case of $B$. sensitivum, scientists used methanol solvent fractionated by ethyl acetate, whereas the solvent in this research was water and unfractionated. Thus it is clear, that is one of the important factors which influence the efficiency of extracting bioactive compound as antioxidant agent are solvent, species and extraction method. This statement is in accordance with that expressed by Sulaiman et al. (2011) and Ngo et al. (2017), that one of important factors that influence the efficiency of bioactive compounds as antioxidant agent from plants is its extraction method and its solvent. .

\section{The relationship between TPC with antioxidant activity}

Based on the result of this research, TPC content of KG plant was $147 \pm 1.24 \mathrm{mgGAE} / \mathrm{gdw}$, the antioxidant capacity equal to ascorbic acid by 69.931 $\mathrm{mgAE} / \mathrm{gdw}$ and equal to trolox by $65.698 \mathrm{mgTE} / \mathrm{gdw}$. We managed to obtained the contribution of kebar grass bioactive component to antioxidant activity was $47.38 \%$ (equal to ascorbic acid) and $44.51 \%$ (equal to trolox), which means that almost half of phenolic compound contained in KG plant can inhibit free radical or oxidant. Thus, the results of this study can reveal KG plants as a potential source of antioxidants that are almost equivalent to vitamin $\mathrm{C}$ (ascorbic acid) and vitamin $\mathrm{E}$ (trolox) that have not previously been reported. The activity of vitamin $\mathrm{C}$ and vitamin $\mathrm{E}$ as antioxidants has been known to have a good effect on improving reproduction, as reported by Christijanti et al. (2010) in Wistar strains that had previously been exposed to allethrin. The relationship between the content of TPC in KG plants with antioxidant activity which expressed as equivalent to ascorbic acid and trolox is a superiority of KG plants as one of the sources of medicinal plants that have double antioxidant actions and has potential as improving reproductive performance.

Scientific information obtained from this study can be used as a material for further development of KG plants as health products, both as a medicinal plant for infertility problems (curative) and as a functional food ingredient for antioxidant sources that prevent a decrease in reproductive performance (preventive). 


\section{CONCLUSION}

Conventional extraction method of KG plant produced relatively high extract yield which is almost similar with maceration extraction method with ethanol $70 \%$ solvent. The phenolic compound composition of KG plant was dominated by flavonoid, tannin, and saponin. By the dominance of the high phenolic content, KG plants have potential as medicinal plants.. It also has good antioxidant activity, which is almost equivalent to vitamin $\mathrm{C}$ (ascorbic acid) and vitamin $\mathrm{E}$ (trolox) as its analogue. Both vitamins are known to greatly contribute to general health, including reproductive health.

\section{ACKNOWLEDGEMENTS}

This research is funded by Ministry of Research, Technology and Higher Education, Directorate of Research and Public Service, Directorate of Research and Development through LPPM IPB University program year 2019 No. 6/E/KPT/2019.

\section{REFERENCES}

Adebayo, I. A., Arsad, H., \& Samian, M. R. (2018). Total Phenolics, Total Flavonoids, Antioxidant Capacities, and Volatile Compounds Gas Chromatography-Mass Spectrometry Profiling of Moringa oleifera Ripe Seed Polar Fractions. Pharmacognosy Magazine, 14, 191 - 194.

Adhikari, P. P., Talukdar, S., \& Borah, A. (2018). Ethnomedicobotanical study of indigenous knowledge on medicinal plants used for the treatment of reproductive problems in Nalbari district, Assam, India. Journal of Ethnopharmacology, 210, 386-407.

Adhikari, P. P., Talukdar, S., \& Borah, A. (2018). Ethnomedicobotanical study of indigenous knowledge on medicinal plants used for the treatment of reproductive problems in Nalbari district, Assam, India. Journal of Ethnopharmacology, 210, 386-407.

Amudha, M., \& Shanmugan, R. (2016). Fertility inducing effect of Cadaba fruticose (L). druce in female albino rats. Internataional Journal of Biology, Pharmacy, and Allied Sciences, 5(4), 850863.

Andarwulan, N., Batari, R., Sandrasari, D. A., Bolling, B., \& Wijaya, H. (2010). Flavonoid content and antioxidant activity of vegetables from Indonesia. Food chemistry, 121(4), 1231-1235.

Andarwulan, N., Dewi K., Riza, A. A., Hardianzah, R., Anna, V. R., \& Bolling, B. W. (2012). Polyphenols, carotenoids, and ascorbic acid in un- derutilized medicinal vegetables. Journal of Functional Foods, 4, 339-347.

Chen, C. C., \& Chan, W. H. (2012). Injurious effects of curcumin on maturation of mouse oocytes, fertilization and fetal development via apoptosis. International journal of molecular sciences, 13(4), 4655-4672.

Christijanti, W., Utami, N., \& Iswara, A. (2011). Efek Pemberian Antioksidan Vitamin C dan E terhadap Kualitas Spermatozoa Tikus Putih Terpapar Allethrin. Biosaintifika: Journal of Biology \& Biology Education, 2(1).

Claudya. N. E., Effendi, E. M., \& Sari, B. L. (2016). Uji efektivitas ekstrak etanol $70 \%$ rumput kebar (Biophytum petersianum) sebagai estrogenik pada tikus putih betina (Rattus norvegicus). Scribd.

Datta, S., Sinha, B. K., Bhattacharjee, S., \& Seal, T. (2019). Nutritional composition, mineral content, antioxidant activity and quantitative estimation of water- soluble vitamins and phenolics by RPHPLC in some lesser used wild edible plants. Heliyon, 5(3).

Handayaningsih, W. (2010). Pengaruh antioksidan vitamin E terhadap jumlah kerusakan sel testis tikus putih (Rattus norvegicus) yang dipapar dengan asap rokok. RESEARCHGATE, 2010(1).

Harborne, J. B. (1998). Phytochemical Methods. London: Chapman Hall Press.

Hernayanti, \& Simanjuntak, S. B. I. (2019). Antioxidant Effect of Chlorella vulgaris on Physiological Response of Rat Induced by Carbon Tetrachloride. Biosaintifika: Journal of Biology \& Biology Education, 11(1), 84-90.

Hyde, M.A., Wursten, B.T., Ballings, P., \& Coates Palgrave, M. (2020). Flora of Zimbabwe: Species information: Biophytum umbraculum.

Iqbal, E., Salim, K. A., \& Lim, L. B. L. (2015). Phytochemical screening, total phenolics and antioxidant activities of bark and leaf extracts of Goniothalamus velutinus (Airy Shaw) from Brunei Darussalam. Journal of King Saud University - Science, 27(3), 224-232.

Juliani, Yuliana, N. D., Budijanto, S., Wijaya, H., \& Khatib A. (2016). Senyawa inhibitor $\alpha$ glukosidase dan antioksidan dari kumis kucing dengan pendekatan metabolomik berbasis FTIR. $J$. Teknol. dan Indus. Pang., 27(1), 17-30

Kumar, B., Shukla, P.K., Niranjan, A., Misra, A., Rawat, A., \& Srivastava, S. (2017). RP-HPLC quantification of five phenolic compounds in Biophytum sensitivum (L.) DC. (Oxalidaceae) and their biological evaluation. Indian Journal of Traditional Knowledge, 16(2), 319-324.

Lisangan, M. M., Syarif, R., Rahayu, W. P., \& Dharmaputra, O. S. (2014). Antifungal Activity of Kebar Grass Leaf Extracts on the Growth of Aflatox- 
igenic Aspergillus flavus in Food Model. International Journal of Sciences: Basic and Applied Research, 17(2), 116-128.

Ly, C., Lelièvre, Y. L., Ferraro, Z. M., Arnason, J. T., Ferrier, J., \& Gruslin, A. (2015). The effects of dietary polyphenols on reproductive health and early development, Human Reproduction Update, 21(2), 228-248.

Mbemya, G. T., Vieira, L. A., Canafistula, F. G., Pessoa, O. D. L., \& Rodrigues, A. P. R. (2017). Reports on in vivo and in vitro contribution of medicinal plants to improve the female reproductive function. Reprodução \& Climatério, 32(2), 109119.

Nahak, G., Mruntyanjay, S., \& Rajani, K. S. (2014). Antioxidant potential and nutritional values of vegetables: A Review. Research Journal of Medicinal Plant, 8(2), 50-81.

Ngo, T. V., Scarlett, C. J., Bowyer, M. C., Ngo, P. D., \& Vuong, Q. V. (2017). Impact of different extraction solvents on bioactive compounds and antioxidant capacity from the root of Salacia chinensis $\mathrm{L}$. Journal of Food Quality, 1(11), 1-8.

Pratomo, H. (2012). Kinerja pasak bumi (Eurycoma longifolia Jack.) dalam peningkatan kualitas reproduksi tikus tikus (Rattus novergicus) jantan. Thesis. Bogor: Sekolah Pascasarjana, Institut Pertanian Bogor.

Rajurkar, N. S., \& Hande, S. M. (2011). Estimation of phytochemical content and antioxidant activity of some selected traditional Indian medicinal plants. Indian journal of pharmaceutical sciences, 73(2), 146-151.

Rattanasena, P. (2012). Antioxidant and antibacterial activities of vegetables and fruits commonly consumed in Thailand. Pakistan Journal of Biological Sciences, 15, 877-882.
Rütti, D., \& Meier,.H. (2012). Multivapor application guide. BÜCHI Labortechnik AG Press.

Sasidharan, S., Chen, Y., Saravanan, D., Sundram, K. M., \& Yoga Latha, L. (2011). Extraction, isolation and characterization of bioactive compounds from plants' extracts. African journal of traditional, complementary, and alternative medicines: AJTCAM, 8(1), 1-10.

Sreeramulu, D., Reddy, C. V. K., Chauhan, A., Balakrishna, N., \& Raghunath, M. (2013). Natural antioxidant activity of commonly consumed plant foods in India: effect of domestic processing. Oxidative Medicine and Cellular Longevity, 2013(6), 1-12.

Sulaiman, S. F., Sajak, A. A. B., Ooi, K. L., Supriatno, \& Seow, E. M. (2011). Effect of solvents in extracting polyphenols and antioxidants of selected raw Vegetables. Journal of Food Composition and Analysis, 24, 506-515.

Telefo, P. B., Tagne, S. R., Koona, O. E., Yemele, D. M., \& Tchouanguep, F. M. (2011). Effect of the aqueous extract of Justicia insularis T. Anders (Acanthaceae) on ovarian folliculogenesis and fertility of female rats. African journal of traditional, complementary, and alternative medicines: AJTCAM, 9(2), 197-203.

Thouri, A., Chahdoura, H., El Arem, A., Omri Hichri, A., Ben Hassin, R., \& Achour, L. (2017). Effect of solvents extraction on phytochemical components and biological activities of Tunisian date seeds (var. Korkobbi and Arechti). BMC complementary and alternative medicine, 17(1), 248.

Titrikou, S., Gadegbeku, K.L., Mouzou, A., Aklikokou, A., \& Gbeassor, M. (2007). Calcium Antagonistic Activity of Biophytum petersianum on Vascular Smooth Muscles of Wistar Rat. IJPT, 6(2), 185-189. 